\title{
Observations of Growth Stages of Diaporthe citri on Epidermal Strips of Onion Bulb
}

\author{
Kotaro Tomono*, Yutaka ARimoto*, Yasuo Homma* and Tomomasa Misato* \\ 伴野広太郎*·有本 裕*・本間保男*・見里朝正*：タマネギりん片上に括ける \\ 黒点病菌の生育過程の観察
}

\begin{abstract}
The whole cycle of fungal growth of Diaporthe citri, i. e., pycnospore germination, appressorial formation, hyphal penetration, penetrated mycelia, pycnidium formation and pycnospore formation was observed on alcohol-treated epidermal strips of onion bulb which might be free from some inhibitors against hyphal penetration. The results obtained on epidermal strips of onion bulb were nearly same as those obtained on citrus leaves or twigs. Therefore, the method using epidermal strips of onion bulb would be very useful for assaying the effects of fungicides on the different growth stages of $D$. citri. The maximum rate of pycnospore germination was approximately 80 to $100 \%$ and that of hyphal penetration was approximately 50 to $70 \%$. The shapes of appressoria were mostly fist-like or globular form and they did not necessarily have relation to hyphal penetration. Therefore, the function of appressorium of $D$. citri seems to adhere on host plants, but the role does not seem to be so important, judging from the fact that the appressorial formation rate is only 20 to $30 \%$. When suspension of pycnospores in pycnidia formed on epidermal strips of onion bulb was inoculated on young citrus leaves, typical symptoms of melanose were observed, indicating that the pycnospores were virulent.
\end{abstract}

(Received April 13, 1979)

\section{Introduction}

Melanose is one of the most important diseases of citrus in Japan having abundant summer rainfall and is caused by the pathogenic fungus, Diaporthe citri (Faw.) Wolf, that induces stem-end $\operatorname{rot}^{22}$. Homma et al. ${ }^{3,8)}$ investigated the mechanism of occurrence of stem-end rot in detail. Detailed study on preventive measures of melanose were also made ${ }^{10,13)}$. For infection of melanose, periods of wetness of fruit or leaves and temperature are important factors?). Recently, Ushiyama ${ }^{12)}$ reported an observation of the growth stages of $D$. citri in which spore germination was observed on slide glass and hyphal penetration on citrus leaves cleared with chloral hydrate. This method, however, is not suitable for examining the effects of fungicides on different growth stages of $D$. citri because the experimental system of spore germination is different from that of hyphal penetration and it is not so easy to clear the citrus leaves to observe the behavior of the pathogen under a microscope. Therefore, an attempt was made to observe the growth stages of $D$. citri by using epidermal strips of onion bulb. By this method, we could observe pycnospore germination, appressorial formation, hyphal penetration, penetrated mycelia and pycnidium formation in one experimental system without any difficult operation.

* The Institute of Physical and Chemical Research, Wako-shi, Saitama 351, Japan 理化学研究所 
We think that this method would be useful for investigating the effects of fungicides on the various growth stages of D. citri. In this paper, fundamental observation of the growth stages of $D$. citri on epidermal strips of onion bulb is reported.

\section{Materials and Methods}

After brown thin skin of onion bulb was removed, the inner epidermis of third or fourth ramenta was cut into $10 \mathrm{~mm} \times 10 \mathrm{~mm}$ in size and these epidermal strips were laid on filter paper containing sterile distilled water to keep moisture in a Petri dish. Pycnospore suspension was prepared by pouring $10 \mathrm{ml}$ of sterile distilled water into autoclaved twig culture and diluting it with sterile distilled water to give an appropriate density (50-60 pycnospores in a field of microscope of 150 magnification). On epidermal strips, 20-30 $\mu$ l of suspension of $D$. citri pycnospores was inoculated with microsyringe. They were incubated at $25 \mathrm{C}$, and pycnospore germination and hyphal penetration were observed at constant intervals with optical microscope. Appressorial formation was observed $24 \mathrm{hr}$ after inoculation with scanning electron microscope. Water drops on epidermal strips were removed $24 \mathrm{hr}$ after inoculation with tissue paper, and a lot of white hyphae on the surface of the epidermal strips were observed 2 or 3 days after removal. After a lot of white hyphae became to be visible, the epidermal strips were kept under sunlight for more than 1 week. Then the pycnidium formation was observed macroscopically and under optical microscope. Pycnospore suspension from the pycnidia was inoculated on young citrus leaves to observe whether or not the pycnospores are virulent.

When newly harvested onion bulbs were used, hyphal penetration was not observed. Therefore, these epidermal strips were used after autoclaving at about $120 \mathrm{C}$ for about 10 min and hyphal penetration was observed. But this method had a shortcoming that epidermal strips became bullate and it was difficult to distinguish penetrated mycelia from lines of epidermal strips. Then, another method was tried by soaking ramenta of these new onion bulb in $80 \%$ ethylalcohol solution. This method was suitable for observing hyphal penetration.

\section{Results}

\section{Pycnospore germination}

On alcohol untreated epidermal strips of onion bulb, no pycnospore germination was observed 1 to $3 \mathrm{hr}$ after inoculation, a few germ tubes were observed $4 \mathrm{hr}$ after inoculation and pycnospore germination rate became about $50 \% 5$ or $6 \mathrm{hr}$ after inoculation, 70-80\% 7 or $8 \mathrm{hr}$ after inoculation, more than $90 \% 12 \mathrm{hr}$ after inoculation and almost $100 \% 14 \mathrm{hr}$ after inoculation.

On alcohol-treated epidermal strips of onion bulb, only a few pycnospores germinated 5 or $6 \mathrm{hr}$ after inoculation, fairly many pycnospores germinated $8 \mathrm{hr}$ after inoculation and pycnospore germination rate became about maximum 12 or $14 \mathrm{hr}$ after inoculation as shown in Fig. 1 . The maximum rate of pycnospore germination was between about 80 to $100 \%$.

In most cases, pycnospores germinated from one side of them as shown in Plate I-1 but in a few cases, they germinated from both ends as shown in Plate I-2.

\section{Appressorial formation}

Appressorial formation of $D$. citri on alcohol-treated epidermal strips of onion bulb was observed with a scanning electron microscope $24 \mathrm{hr}$ after inoculation. 


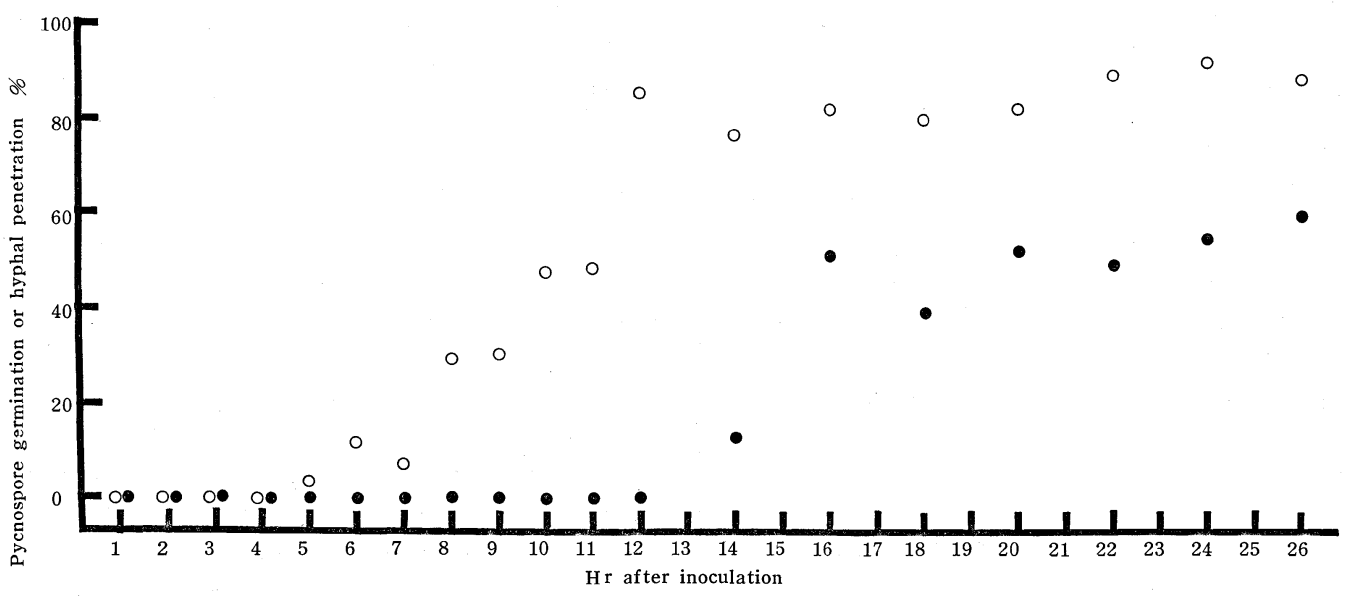

Fig. 1. The time courses of pycnospore germination and hyphal penetration of Diaporthe citri on the epidermal strips of onion bulb soaked in $80 \%$ ethylalcohol solution for more than 3 days.

$\bigcirc$ : pycnospore germination, : hyphal penetration.

Appressoria of $D$. citri were indeterminate forms, namely many of them were fist-like or globular form as shown in Plate I-4, 5, 6 and 7 . The appressorial formation rates at $24 \mathrm{hr}$ after inoculation were about 20-30\% of all germinated pycnospores. The lengths of germ tubes before appressorial formation were about 1-10 times of major axis of pycnospore.

Most mycelia penetrated without appressorial formation as shown in Plate I-3. There were three kinds of appressorial formation. First was that no hyphal penetration was observed after appressorial formation (Plate I-5). Second was that hyphal penetration was done shortly after appressorial formation (Plate I-6). Third was that hyphal penetration was done just after appressorial formation (Plate I-7). Therefore, appressorial formation of $D$. citri does not necessarily have relation to hyphal penetration.

\section{Hyphal penetration}

At first, hyphae penetrated vertically as shown in Plate I-8 and then elongated in the cells of epidermal strips as shown in Plate II-10c. On alcohol treated epidermal strips of onion bulb, hyphal penetration began about $14 \mathrm{hr}$ after inoculation and hyphal penetration rate reached nearly $50 \% 16 \mathrm{hr}$ after inoculation as shown in Fig. 1. After that, penetration rates remained almost constant. The maximum rate of hyphal penetration was usually about $50 \%$ and even reached $70 \%$ of germinated pycnospores. Mycelia which did not penetrated $24 \mathrm{hr}$ after inoculation elongated on the surface of epidermal strips and they sometimes made mycelial mats $48 \mathrm{hr}$ after inoculation. Germ tubes did not always penetrate from one point and sometimes penetrated from more than 2 points (Plate I-9). Mycelia on the surface of epidermal strips became wider after penetration as compared with those before penetration (Plate I-9). Penetrated mycelia elongated in the cells of epidermal strips as long as mycelia which elongated on epidermal strips, and sometimes dichotomy mycelia were found (Plate II-10c). The lengths of mycelia before penetration were about 1-15 times of major axis of pycnospore. On alcohol-treated epidermal strips of onion bulb, mycelia before penetration were shorter than on alcohol-untreated epidermal strips of onion bulb and fairly many pycnospores penetrated just after 
germination.

When autoclaved epidermal strips were used, the maximum rate of hyphal penetration was between about 30 to $50 \%$ and the penetraiton rates increased rapidly from about 21 to $24 \mathrm{hr}$ after inoculation.

\section{Pycnidium formation}

When epidermal strips of onion bulb were kept under sunlight for more than 1 week, pycnidia were observed macroscopically or under optical microscope (Plate II11,12 and 13). Pycnospores in the pycnidia had the same shape as those formed on autoclaved twig culture (Plate II-14). About 10 days after inoculation of pycnospores in pycnidia formed on epidermal strips of onion bulb, typical symptoms of melanose were observed on young citrus leaves, indicating that the pycnospores were virulent (Plate II-15).

\section{Discussion}

There are three main nutrients in citrus leaves, namely, fructose, glucose and sucrose ${ }^{4)}$. Of these three, fructose is the most important for spore germination and mycelial elongation ${ }^{4}$. Among nutrients in citrus leaves, water soluble pectin is not extracted in alcohol solution. When no nutrient is added to pycnospore suspension, the maximum of pycnospore germination rate on slide glass is about 40 $\%$ at most. In the experiment presently reported, no nutrient was added to pycnospore suspension. The time course of pycnospore germination rates on alcohol -untreated epidermal strips of onion bulb was nearly the same as that on young citrus leaves ${ }^{1)}$, and the maximum rates of pycnospore germination on alcohol-treated and -untreated epidermal strips of onion bulb were both between about 80 to $100 \%$. Therefore, epidermal strips of onion bulb seemed to have some nutrients to promote spore germination.

Kuramoto et al.9) and Ushiyama ${ }^{12)}$ reported about appressorial formation, but the figure of appressorium was not clear because they observed them with optical microscope. It was difficult to observe them even with scanning electron microscope. Usually, appressoria are thought to possess two functions. One is that fungi like Pyricularia oryzae ${ }^{6}$ ) form appressorium as preliminary organ of hyphal penetration, and hyphal penetration is done just after appressorial formation. The other is that fungi like Leveillula taurica ${ }^{5)}$ form appressorium to make it easy to adhere on host plants. The function of appressorium of $D$. citri is not the former case, because the appressorial formation of $D$. citri does not necessarily have relation to hyphal penetration. Therefore, the function of appressorium of $D$. citri seems to adhere on host plants, but the role does not seem to be so important, judging from the fact that the appressorial formation rate of $D$. citri is only $20-30 \%$ and one pycnospore does not form two or more appressoria on mycelial development.

Tanaka et al. ${ }^{11)}$ and Kuramoto et al. ${ }^{9)}$ observed hyphal penetration, but they only cut the penetrated part of plant tissues and observed it under optical microscope or observed penetrated cells after staining the tissue. These methods were not necessarily suitable for examining effects of fungicides on hyphal penetration or penetrated hyphae. When epidermal strips of onion bulb were used, it was very easy to observe hyphal penetration or penetrated mycelia.

Hyphal penetration was observed on epidermal strips of newly harvested onion bulb only when the ramenta were soaked in $80 \%$ ethylacohol solution for more than 3 days. The reason might be that inhibitors like catecol in epidermal strips were extracted. 
In order to clarify whether onion bulbs have inhibitory materials or not, ethylalcohol was removed from $80 \%$ ethylalcohol solution in which ramenta of onion bulb had been soaked and the residue which contained extracts from onion bulbs was diluted into $10^{-1}$ and $10^{-2}$ times and added to pycnospore suspension of same volume. When this suspension was inoculated on alcohol-treated epidermal strips of onion bulb, hyphal penetration was restrained perfectly but germ tubes were fat and long. These facts mean that onion bulbs might contain some inhibitory materials for hyphal penetration and some nutrients to promote growth of germ tubes.

On upper surface and lower surface of citrus leaves, hyphal penetration began about $8 \mathrm{hr}$ after inoculation and hyphal penetration rate became about $50 \% 12 \mathrm{hr}$ after inoculation and hyphal penetration rate did not increase so much after that ${ }^{11}$. On alcohol-treated epidermal strips of onion bulb, hyphal penetration began $14 \mathrm{hr}$ after inoculation and hyphal penetration rate became nearly maximum about $16 \mathrm{hr}$ after inoculation.

On upper surface of citrus leaves, D. citri penetrated from sutures of cells and on lower surface of citrus leaves, $70-80 \%$ of penetrated mycelia penetrated from stomata and 20-30\% of penetrated mycelia penetrated from sutures of cells ${ }^{1)}$. On epidermal strips of onion bulb which had no stomata, cuticular penetration was done. However, D. citri did not penetrate only from sutures of cells but penetrated from everywhere of cells on epidermal strips of onion bulb. Only about $5 \%$ of germ tubes penetrated from sutures of cells. And after hyphal penetration, mycelia elongated in cells of the epidermal strips of onion bulb. This might correspond to mycelial elongation in cells of mesophyll of citrus leaves.

On epidermal strips of onion bulb, pycnidium formation was observed and pycnospores in the pycnidia were virulent. Therefore, we could observe every growth stages of $D$. citri, i. e., pycnospore germination, appressorial formation, hyphal penetration, penetrated mycelia and pycnidium formation in one experimental system. The method described above (Homma et al. method) was very suitable for observing the growth stages of $D$. citri and this method may be very helpful for the investigation of effects of fungicides on the different growth stages of D. citri.

\section{Literature cited}

1. Arimoto, Y., Homma, Y. and Misato, T. (1978). Ann. Phytopath. Soc. Japan $44: 372$ (abstr.).

2. Floyd, B. F. and Stevens, H. E. (1912). Fla. Agr. Exp. Sta. Bull. 111 : 1-16.

3. Homma, Y. (1975). Shokubutsubōeki $29: 138-142$.

4. Homma, Y., Arimoto, Y. and Misato, T. (1979). Ann. Phytopath. Soc. Japan 45 : 9-16.

5. Homma, Y., Arimoto, Y., Takahashi, H., Ishikawa, T., Matsuda, I. and Misato, T. Ibid. (in press).

6. Homma, Y., Takahashi, H., Arimoto, Y., Kojima, F. and Misato, T. (1977). Ibid. 43:7071 (abstr.).

7. Homma, Y. and Yamada, S. (1969). Bull. Hort. Res. Sta., Japan, Ser. B 9 : 85-96.

8. Homma, Y. and Yamada, S. (1969). Ibid. $9: 99-115$.

9. Kuramoto, T. and Yamada, S. (1975). Bull. Fruit Tree Res. Stn. B $2: 75-86$.

10. Ōmori, H. and Matsumoto, H. (1967). Bull. Ehime Fruit Tree Exp. Sta. $5: 47-57$.

11. Tanaka, S. and Nakamura, S. (1950). Hort. Assoc. Japan $19: 177-184$.

12. Ushiyama, K. (1976). Bull. Kanagawa Hort. Exp. Sta. 23 : 11-18.

13. Yamamoto, S. (1967). Agr. Hort. $42: 1235-1238$. 
和 文 摘 要

$$
\begin{gathered}
\text { タマネギりん片上における黒点病菌の生育過程の観察 } \\
\text { 伴野広太郎・有本 裕・本間保男・見里朝正 }
\end{gathered}
$$

菌糸侵入に対する阻害物質をアルコールで抽出除去したタマネギりん片上皮上で，黒点病菌の全生育過 程, すなわち, 胞子発芽, 付着器形成, 菌系侵入, 侵入後の菌系, 柄子殼の形成, 柄子殼中の柄胞子の形成 が観察された。しかも, それらの形成率や時間変化等は, ミカンの葉や枝の上で観察された結果とほぼ同じ であった。したがって, タマネギりん片上皮を使ったこの方法は, 黒点病菌の各生育過程に及ぼす殺菌剤の 効果在検討するのに非常に有用であろう。胞子発芽率の最大值は約 80-100\%で, 菌系侵入率の最大值は約 50一70\%であった。付着器の形は, ほとんどが, こぶし形ないしは球形であった。そして, 付着器形成之菌 系侵入とは, かならずしあ一定の関係があるとは思われなかった。したがって, 黒点病菌の付着器は一般に 宿主に付着する為の器官と思われるが，20-30\%程度の形成率から判断して，その役割はそれほご重要では ないと解勫される。タマネギりん片上皮上に形成された柄子殼中の柄胞子は, 展葉初期のミカンの葉に接種 すると展型的な黒点病の病斑を形成したので, 病原性のあることが確認された。

\section{Explanation of Plates}

\section{Plate I}

1. Pycnospore germination on epidermal strips of onion bulb soaked in $80 \%$ ethylalcohol solution for more than 3 days, $12 \mathrm{hr}$ after inoculation. Bar : $5 \mu \mathrm{m}$ (SEM).

2. Pycnospore germination from both ends on epidermal strips of onion bulb, $12 \mathrm{hr}$ after inoculation. Bar : $20 \mu \mathrm{m}$ (Optical microscope).

3. Penetration without appressorial formation on epidermal strips of onion bulb soaked in $80 \%$ ethylalcohol solution for more than 3 days, $48 \mathrm{hr}$ after inoculation. Bar : $5 \mu \mathrm{m}$ (SEM).

4. Appressorial formation on epidermal strips of onion bulb soaked in $80 \%$ ethylalcohol solution for more than 3 days, $48 \mathrm{hr}$ after inoculation. Bar : $5 \mu \mathrm{m}$ (SEM).

5. Appressorial formation on epidermal strips of onion bulb soaked in $80 \%$ ethylalcohol solution for more than 3 days, $24 \mathrm{hr}$ after inoculation. Bar : $5 \mu \mathrm{m}$ (SEM).

6. Hyphal penetration shortly after appressorial formation on epidermal strips of onion bulb soaked in $80 \%$ ethylalcohol solution for more than 3 days, $48 \mathrm{hr}$ after inoculation. Bar : $5 \mu \mathrm{m}$ (SEM).

7. Hyphal penetration just after appressorial formation on epidermal strips of onion bulb soaked in $80 \%$ ethylalcohol solution for more than 3 days, $48 \mathrm{hr}$ after inoculation. Bar : $5 \mu \mathrm{m}$ (SEM).

8. Vertically penetrated mycelium on epidermal strips of onion bulb, $14 \mathrm{hr}$ after inoculation. Bar : $10 \mu \mathrm{m}$ (Optical microscope).

9. Hyphal penetration from 2 points on epidermal strips of onion bulb, $23 \mathrm{hr}$ after inoculation.

\section{Plate II}

Bar : $20 \mu \mathrm{m}$ (Optical microscope).

10. Hyphal penetration on epidermal strips of onion bulb, $27 \mathrm{hr}$ after inoculation. Bar: $20 \mu \mathrm{m}$ (Optical microscope).

10a. The depth of focus was adjusted to pycnospore on epidermal strips of onion bulb. 10b. The depth of focus was adjusted to vertically penetrated mycelia in epidermal strips of onion bulb.

10c. The depth of focus was adjusted to mycelia elongating in epidermal strips of onion bulb.

11. Pycnidium formation on epidermal strips of onion bulb soaked in $80 \%$ ethylalcohol solution for more than 3 days. Bar : $50 \mu \mathrm{m}$ (Optical microscope). 
12. Pycnidium formation on epidermal strips of onion bulb soaked in $80 \%$ ethylalcohol solution for more than 3 days. Bar : $50 \mu \mathrm{m}$ (Optical microscope).

13. Pycnidium formation on epidermal strips of onion bulb soaked in $80 \%$ ethylalcohol solution for more than 3 days. Bar : $50 \mu \mathrm{m}$ (Optical microscope).

14. Pycn ospores from pycnidia formed on epidermal strips of onion bulb soaked in $80 \%$ ethylalcohol solution for more than 3 days. Bar : $20 \mu \mathrm{m}$ (Optical microscope).

15. Lesions of melanose on young citrus leaves caused by pycnospores in pycnidia formed on epidermal strips of onion bulb soaked in $80 \%$ ethylalcohol solution for more than 3 days. Bar : $50 \mu \mathrm{m}$ (Optical microscope).

\section{Abbreviation in Figures}

a, appressorium; gt, germ tube; hp, hyphal penetration ; 1 , lesion ; p, pycnidium ; pm, penetrated mycelium; s, pycnospore ; vpm, vertically penetrated mycelium. 

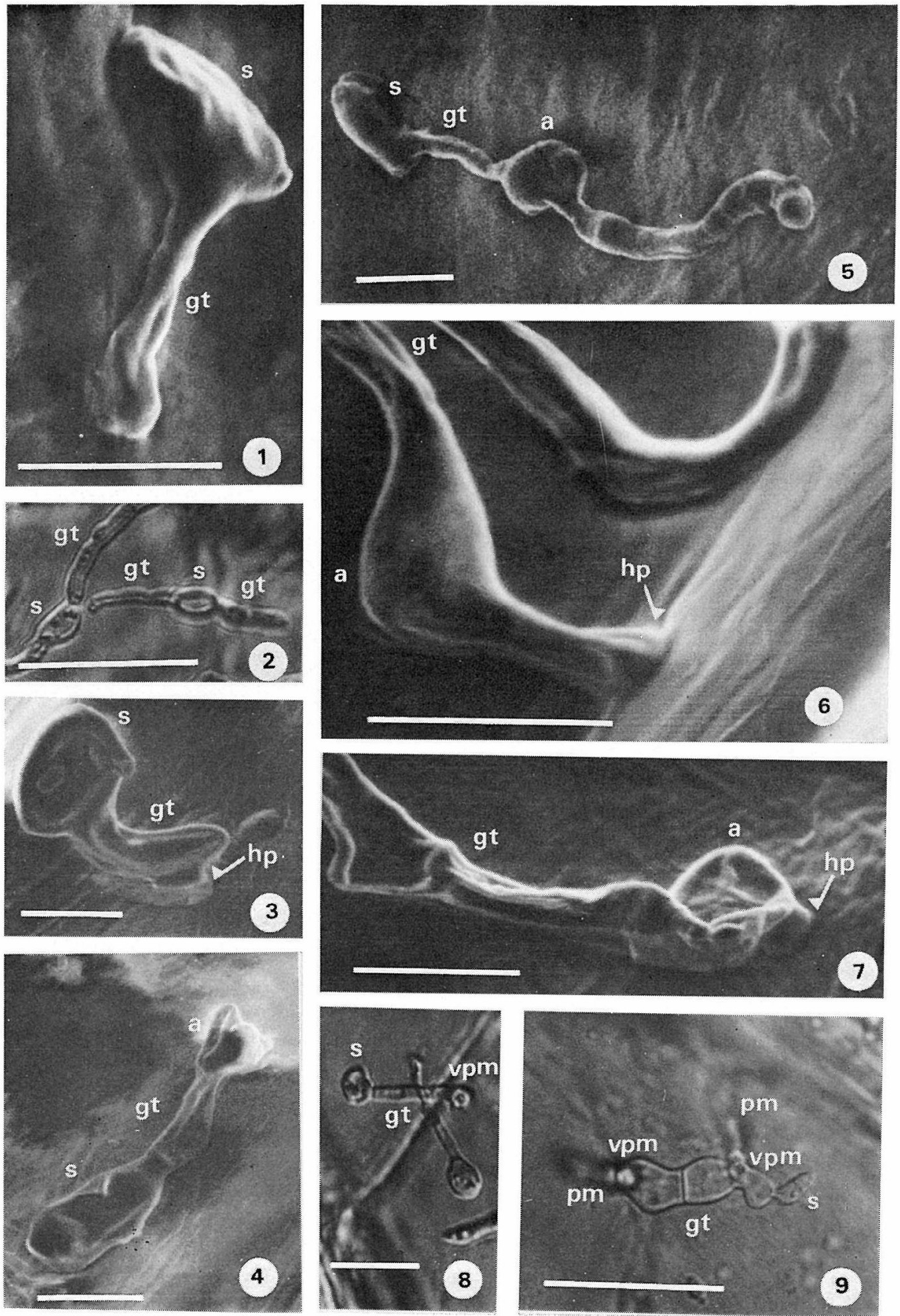

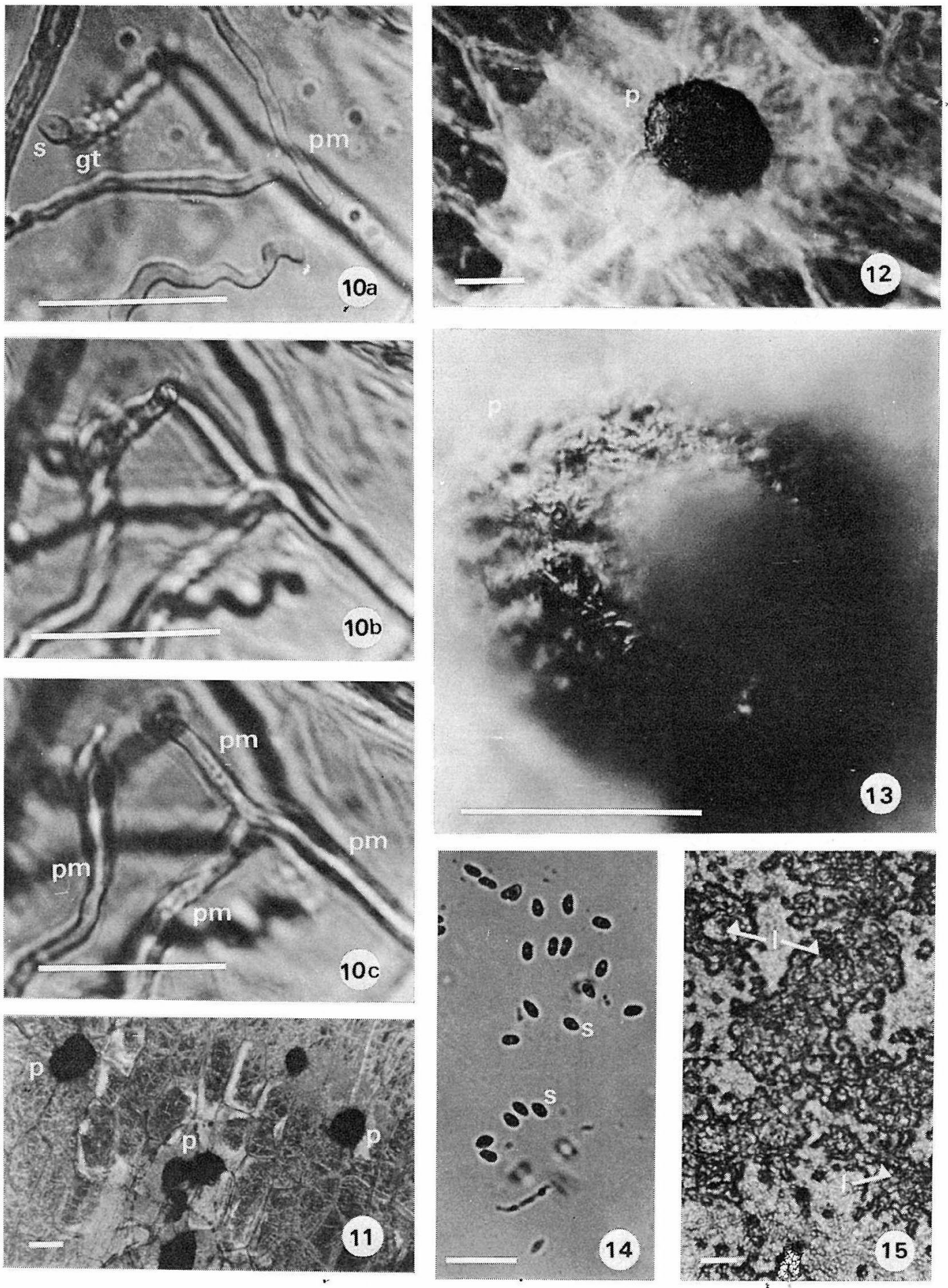